\title{
Climate study in different phases of medical students of medical colleges of Bangladesh
}

\author{
Nurun Nahar ${ }^{1}$, Md. Humayun Kabir Talukder ${ }^{2}$, Md. Tafazzal Hossain Khan $^{3}$, Tahmina Nargis ${ }^{4}$, \\ Shegufta Mohammad ${ }^{5}$ Nasrin Akhter ${ }^{6}$
}

\begin{abstract}
Climate is the soul and spirit of medical college and students' experiences of the climate are a useful basis for modifying and improving the quality of educational environment. The present study was undertaken to identify how the students perceive the educational environment in a newly restructured curriculum using the Dundee Ready Education Environment Measure (DREEM). The inventory was administered to 1903 medical students $\left(3^{\text {rd }}, 4^{\text {th }}\right.$ and $5^{\text {th }}$ year $)$ of MBBS course adopting purposive sampling. The mean DREEM total score and mean score for five essential domains were found significantly different in different phase of medical students. DREEM total score were found to be highest for $3^{\text {rd }}$ year students $(119 / 200)$ and lowest for $5^{\text {th }}$ year students $(105 / 200)$ but all the three groups of students perceive the environment as positive. $3^{\text {rd }}$ year students also scored high than $4^{\text {th }}$ and $5^{\text {th }}$ year students in five domains. All the three groups of students identify problems in environment and give opinion that there are many issues need to improve with special attention to perception of atmosphere and social self perception. The results are the first data obtained from the students about the educational environment and give important feedback to curriculum planners and change managers of the faculty for necessary improvement.
\end{abstract}

Key words: perception, medical education, educational environment, medical colleges.

\footnotetext{
${ }^{1}$ Assoc. Prof. Pharmacology, East West Medical College, Turag, Uttara, Dhaka

${ }^{2}$ Assoc. Prof. (Teaching Methodology) \& Course Director, CME

${ }^{3} \mathrm{MD}$ (Neonatology) Thesis part, BSMMU, Dhaka.

${ }^{4}$ Research Associate, CME

${ }^{5}$ Assistant professor, Dental Public Health

Department, Institute of Medical Technology, Mirpur, Dhaka

${ }^{6}$ Assistant Professor, Gynae \& Obs, SSMC
}

\begin{abstract}
Introduction
The concept of climate is very inclusive and refers to everything that is happening in the classroom or department or faculty or university. It is argued that the climate is the soul and spirit of the medical college environment and curriculum ${ }^{1}$. Climate measurement comprehensively assesses what is happening, or how things are in, say the medical college. In more prosaic terms, educational climate is a manifestation or operationalization of the educational environment and of the curriculum. Students' experiences of the climate are related to their achievements, satisfaction and success ${ }^{1}$.
\end{abstract}

There is an increasing interest and concern regarding the role of learning environment in undergraduate medical education in the recent years. Educational environment is one of the most important factors determining the success of an effective curriculum ${ }^{2}$. The quality of educational environment has been identified to be crucial for effective learning. A good learning environment is vital for the delivery of quality training ${ }^{3}$.

Curriculums most significant manifestation and conceptualization is the environment educational and organizational which embraces everything that is happening in the medical college ${ }^{4}$. Any curriculum generates and establishes environment and changes in curriculum are thus essentially changes in environment. The environment, as perceived, may be designated as climate. There is a proven connection between the environment and the valuable outcomes of students' achievement, satisfaction and success ${ }^{4}$. It can be concluded that a study of the curriculum is largely dependent on a study of the environment or climate ${ }^{1}$. Positive environment and positive learning outcome appears to go together ${ }^{5}$.

The educational environment makes an impact on students learning experiences and outcomes ${ }^{6}$. Educational environment influences how, why and what students learn. It has a personality. Studying this unique personality enables faculty, administrators and students to answer the question, "What is medical education here really like?" 7 . 
The undergraduate MBBS curriculum in our country is still in the traditional mode. Generally it is teacher centred, discipline based with no elective modules. The teaching depends mainly on information gathering where the teacher is the main source of information. The main part of the curriculum consists of lecture, tutorial, practical and ward teaching classes with a limited number of problem based sessions. The learning task is to reproduce the subject matter in the final examination. Generally students see learning as something done to them by the teacher.

However in 2002, curriculum planners decided to implement a new comprehensive medical curriculum that is integrated and organized in three phases. Phase 1 is pre-clinical $\left(1^{\text {st }}\right.$ and $2^{\text {nd }}$ year $)$, phase 2 is para-clinical $\left(3^{\text {rd }}\right.$ and $4^{\text {th }}$ year $)$ and phase 3 ( $5^{\text {th }}$ year $)$ is clinical. Educational innovation, such as a new curriculum is about introducing and implementing change, but unfortunately it is also a fact that both students and faculty find a new curriculum stressful to implement ${ }^{8}$. This new curriculum is now being going to evaluation. There may be chance of change of perception of different phase of medical students though they study in the same environment. However no study has been yet done to assess student's perception of educational environment in different phase. So it is essential that a base line study is conducted to assess how the different phase students perceive their environment as the learning environment affects students' motivation and achievement and it is also important to get feedback from the students on how they are experiencing their climate.

Inventories measuring educational environment in medical education are widely being used. In the present study DREEM (Dundee Ready Education Environment Measure) was used. It is a reliable and validated instrument that identifies specific problem areas within an institution for different components of educational environment 9,10 . The present study was undertaken with the objectives1) To identify and compare perception of different phase medical students regarding educational environment 2) To find out specific problem of educational climate in these three groups of students.

\section{Methods}

The Dundee Ready Education Environment Measure (DREEM) has been used as a tool to gather information about the educational environment in many institutions $8,11,12$. It was originally developed at Dundee and has been validated as a universal diagnostic inventory for assessing the quality of educational environment of different institution ${ }^{8}$. DREEM is a 50 items inventory consisting of five subscales or domains such as- 1) students perceptions of learning (SPL) 2) students perceptions of teachers (SPT) 3) students academic self perceptions (SASP) 4) students perceptions of atmosphere (SPA) and 5) students social self perceptions (SSSP). Each item scored on a five-point likert scale with $4=$ Strongly Agree, 3 = Agree, $2=$ Unsure, $1=$ Disagree and 0 $=$ Strongly Disagree. Nine of the 50 items (4, 8, 9, $17,25,35,39,48,50)$ were negative and scored in reverse so that a higher score indicates a more positive reading 9 .

The questionnaire was administered to 1903 medical students' $\left(3^{\text {rd }}\right.$ and $4^{\text {th }}$ and year $5^{\text {th }}$ year) of fifteen medical colleges of Bangladesh. The questionnaire was administered at the end of a scheduled lecture class on different occasions. Before administration the questionnaire the class was addressed regarding the purpose and different aspects of questionnaire for providing appropriate information, stressing the anonymity of the participants and the fact that the data could not be tracked to individual participants. It was also explained that the data would be used for quality assurance as well as for research purpose and requested the students' cooperation, making it clear that participants would be entirely volunteer basis. After distribution they were allowed 20 minutes to fill up the questionnaire and then the completed questionnaire were returned back in the same class.

The inventory yields two types of information: mean total score for 50 items or each of its 5 subscales and individual item mean score for each of the 50 item. To pinpoint more specific strength and weaknesses within the learning environment items that have a mean score of 3 or over were taken as positive points. Any item with a mean of 2 or less should be examined more closely as they indicate problem areas and items with a mean between 2 and 3 were considered as aspects of environment that could be enhanced ${ }^{13}$. Score for categorized domains, total score and each item were expressed as mean and data were analyzed using the statistical package SPSS (11.5 version) and student's t-test were used to determine statistically significant difference $(\mathrm{p}<0.05)$ for all the comparison. 


\section{Results}

Total respondent were 1903. Among them 475 students of $3^{\text {rd }}$ year, 989 students of $4^{\text {th }}$ year and 439 students of $5^{\text {th }}$ year respectively. Response rate were $99.8 \%$.

Table1 Shows mean \pm SD score for five domain and total score for the three groups of students. Total DREEM score were $119.5 / 200$ for $3^{\text {rd }}$ year students, $108.4 / 200$ for $4^{\text {th }}$ year students and $105.3 / 200$ for $5^{\text {th }}$ year of students. There were significant difference in perception among the three groups of students and highest score were found in $3^{\text {rd }}$ year and lowest score in $5^{\text {th }}$ year students.

Regarding five domains the mean scores for $3^{\text {rd }}$ year students were 31/48(SPL), 27/44(SPT), 20/32(SASP), 25/48(SPA), 14.7/28(SSSP) respectively. While $4^{\text {th }}$ year students scored $27 / 48$ (SPL), 23/44(SPT), 19/32 (SASP), 23/48(SPA), $14 / 28(\mathrm{SSSP})$ and $5^{\text {th }}$ year students scored 25/48(SPL), 22/44(SPT), $19 / 32 \quad$ (SASP), 23/48(SPA), 14.5/28(SSSP) respectively. In five essential domains year 3 students scored high in every domain than $4^{\text {th }}$ and $5^{\text {th }}$ year of students. When the domain score were compared $3^{\text {rd }}$ year students scored significantly high in all domain than $4^{\text {th }}$ year of students. While $4^{\text {th }}$ year students scored significantly high than $5^{\text {th }}$ year in only two domain i.e. students perception of learning and teachers. $3^{\text {rd }}$ year students also scored significantly high than $5^{\text {th }}$ year students regarding all domain except students social self perception. No significant differences were found between $4^{\text {th }}$ and $5^{\text {th }}$ year of students regarding students' academic self perception, students' perception of atmosphere and social self perception.

Table 2 Shows mean score for each DREEM item of the three groups of students and comparison among the three groups. The score were compared between $3^{\text {rd }}$ year with $4^{\text {th }}$ year, between $4^{\text {th }}$ year with $5^{\text {th }}$ year and between $3^{\text {rd }}$ year with $5^{\text {th }}$ year of students. Out of the 50 items mean score of 16 items were found to be below 2, two to be found scored above 3 for all the three groups of students. The lowest score being in item 8 i.e teachers ridicule the students and the highest score in item 2 i.e teachers are knowledgeable for all the three group of students. On comparing the item mean score for the three groups of students 17 items (1, $2,7,12,13,16,22,24,29,30,32,37,39,40,44$, $48,49)$ shows significant difference in perception and only four items shows no significant difference i.e. Learning strategies which worked for me before continue to work for me now, the atmosphere is relaxed during tutorials /seminars, the enjoyment outweighs the stress of studying medicine, I am rarely bored on this course.

\section{Discussion}

Teaching is known to be not only related to giving information and sharing experiences but producing a contextually or/and environmentally related learning as well ${ }^{4}$. The curriculum change was expected to build up a better educational environment, perceived as good by students. A continuous improvement in the educational environment of a curriculum is only possible by defining its weakness and strengths thus; monitoring the perceptions of students at different stages about the educational environment is critical 14

While comparing the total mean score the result of the present study shows that $3^{\text {rd }}$ year students $(119 / 200)$ have a more positive perception of the educational environment than $4^{\text {th }}(108 / 200)$ and $5^{\text {th }}$ $(105 / 200)$ year of students. Till ${ }^{9}$ and Abraham et al 15 found highest score in first year $(113 / 200$; $119 / 200)$ than $3^{\text {rd }}$ year $(79 / 200 ; 114 / 200)$ of students. On the other hand Jiffry et al ${ }^{11}$ and Demiroren et al ${ }^{14}$ found paraclinical students scored high $(109 / 200 ; 123 / 200)$ than clinical students $(107 / 200 ; 109 / 200)$. Our finding correlate with Jiffry et al ${ }^{11}$ and Demiroren et al ${ }^{14}$. High score in $3^{\text {rd }}$ year may be due to they at first come in contact with patient in the course. Low score in $4^{\text {th }}$ year may be due to they are in stress for $2^{\text {nd }}$ professional examination and it is critical to discuss why the score of $5^{\text {th }}$ year are lowest among the three groups of students.

To better define the weakness and strength of educational environment the five domains and corresponding items of DREEM were comparatively interpreted. In students perception of learning (SPL) $3^{\text {rd }}$ year $(31 / 48)$ students perceive more positive than $4^{\text {th }}(27 / 48)$ and $5^{\text {th }}$ year $(25 / 48)$ of students. In this domain among the 12 items three items scored less than 2 in all group of students are teaching is student / teacher centered and overemphasize factual learning and these items should be considered for evaluation. Item 7 i.e teaching is sometimes stimulating scored $>3$ in three group of students. Other eight items scored $>2$ but $<3$ and in every item $3^{\text {rd }}$ year perceive more positive than $4^{\text {th }}$ and $5^{\text {th }}$ year of students. Such a significant difference in perception might arise from the different learning environments in paraclinical and clinical stages as has been emphasized previously elsewhere ${ }^{16}$. Our findings are partially correlate with others $11,14,15$ and indicate the need to recheck clinical training in the new curriculum as their perception differ with paraclinical students.

In students perception of teacher (SPT) $3^{\text {rd }}$ year (27/44) students scored significantly high than $4^{\text {th }}$ $(23 / 44)$ and $5^{\text {th }}(22 / 44)$ year of students. $3^{\text {rd }}$ year 
and $4^{\text {th }}$ year students perceive SPT as moving in right direction but $5^{\text {th }}$ year students opined in need of some retraining for teachers. All the three group of students scored $<2$ in item 8 and 39 i.e. teacher ridicule them and get angry in classes and these items need attention to improve. In item 2 (teachers are knowledgeable) $3^{\text {rd }}$ and $4^{\text {th }}$ year students scored $>3$ but $5^{\text {th }}$ year students scored $<3$. Other 8 items scored $>2$ but $<3$ which need to be enhanced i.e. teachers are not patient, authoritarian attitude, communication skill and criticism of teacher, giving example, feedback and preparation of class need to be evaluated. Our observation partially correlate with Demiroren et al ${ }^{14}$ and Jiffry et al ${ }^{11}$ where they found less score in clinical students but Abraham et al ${ }^{15}$ found high score in clinical students. The results indicate that there is need some training for teacher and we should more careful about clinical training.

Regarding academic self perception (SASP) all the three group students feel more on the positive side and $3^{\text {rd }}$ year students scored high than $4^{\text {th }}$ and $5^{\text {th }}$ year of students. In this domain one item i.e. they are able to memorise all they need scored $<2$ in all the three groups and no item scored $>3$ and other item scored $>2$ but $<3$. One item shows no significant difference among three group of students i.e. learning strategies which work for them before continue to work for them now. There is significant differences were found between $3^{\text {rd }}$ with $4^{\text {th }}$ and $5^{\text {th }}$ year students but no significant difference were found between $4^{\text {th }}$ and $5^{\text {th }}$ year of students. Our finding correlate with Demiroren et al ${ }^{14}$ where they found clinical students scored less than paraclinical whereas Jiffry et al ${ }^{11}$ found low score for paraclinical than clinical students. In this domain all the items need special attention for improvement so that all the students feel confident about their academic perception.

In domain 4 (SPA) the $4^{\text {th }}$ and $5^{\text {th }}$ year students opined there are many issues that need changing but $3^{\text {rd }}$ year students perceive a more positive atmosphere. In this domain all the students scored $<2$ in six items i.e. atmosphere during ward/ lecture teaching, cheating of college, disappointing experience, stress during studying the course, asking question during class and one item scored 3 i.e. feeling of comfortable in class socially. Other items scored $>2$ but $<3$ which need to be enhanced. In two items shows no significant difference in perception among the three groups of students i.e. atmosphere not relaxed during seminars/tutorials and can not able to ask question what they want. Same observations were made by others ${ }^{11},{ }^{14}$. It is very well known that the atmosphere perceived actually represents the real life educational environment and thus the dynamism of curriculum. Special attention should be given to improve atmosphere of lecture, ward teaching, seminar/tutorials and steps should be take to identify the source of stress with remedial measure. Results clearly shows that the actual practice need a critical review and clinical teaching should be restructured according contemporary approaches and with attention to the common pitfalls.

Students' social self perceptions were not a nice place for all the three groups of students. Our results not correlate with others, where Demiroren et al ${ }^{14}$ found high perception in paraclinical than clinical students however Abraham et al ${ }^{15}$ and Jiffry et al ${ }^{11}$ found high score in clinical students than preclinical students. In this domain among the seven items four items scored $<2$ and one item scored 3 in all the three group of students. Al the students opined that they had good friend in the college. Non significant differences were found in item 14 i.e. they bored in the course. So remedial measures should be taken to correct the areas which scored $<2$ i.e. support system for students who are in stress, enjoyment during the course and pleasant accommodation. This result should be discussed not only at the curriculum planner level but should also urge the administrators to establish a social and academic support service for students.

Study of climate are undertaken in order to determine how our students experience the environment generated by a curriculum. Item with low mean scores $(<2)$ required urgent remedial action and it was found that the DREEM inventory was effective as diagnostic tool in order to identify areas of most concern. The results obtained in this study were thus used to guide strategic planning and the institutional focus of available resources. In order to manage change successfully it is also necessary to obtain regular evaluation and feedback, as it is only through information obtained in this way alteration can be made, mistakes corrected and momentum maintained ${ }^{9}$.

\section{References}

1. Genn JM. AMEE Medical Education Guide No-23 (Part 2): Curriculum, environment, climate,

quality and change in medical education- a unifying perspective. Medical Teacher. 2001; 23: $445-54$.

2. Bassaw B, Roff S, Mc Aleer S, Roopnarinesingh S, DeLisle J, Teelucksingh S, Gopaul S.

Students'perspectives on the educational environment, Faculty of medical sciences, Trinidad. 
Medical Teacher. 2003; 25: 522-526.

3. Roff S, McAleer S, Ifere OS \& Bhattacharya S. A global diagnostic tool for measuringeducational environment comparing Nigeria and Nepal. Medical Teacher. 2001; 23(4): 377-81.

4. Genn JM. AMEE Medical Education Guide No-23 (Part 1): Curriculum, environment, climate,

quality and change in medical education- a unifying perspective. Medical Teacher. 2001; 23: 337- 44 .

5. Pimparyan P, Roff S, Mc Aleer S, Poonchai B, Pemba S. Educational environment, Students approaches to learning and academic achievement in a Thai nursing school. Medical Teacher. 2000; 22: 359-64.

6. Roff S, McAleer S, Ifere OS, Bhattacharya S. A Global diagnostic tool for measuring educational environment conparing Nigeria and Nepal. Medical Teacher. 2001; 23(4): 378-82.

7. Genn JM, Harden RM. What is medical education here really like? Suggestions for action research studies of climates of medical education environments. Medical Teacher. 1996: 8(2): 111-24.

8. Roff S, McAleer S, Harden RM, Al-Qahtani M, Ahmed AU, Deza H, Groenen G, Primparyon $\mathrm{P}$

Development and validation of the Dundee Ready Education Environment Measure (DREEM).

Medical Teacher. 1997; 19: 295-98.

9. Till H. Climate Studies: Can students' perceptions of the ideal educational environment be of use for institutional planning and resource utilization. Medical Teacher. 2005; 27: 332-37.
10. Filho GO, Vieira JE, Schonhorst L. Psychometric properties of the Dundee Ready Educational Environment Measure (DREEM) applied to medical residents. Medical Teacher. 2005; 27: 343-47.

11. Jiffry MTM, McAleer S, Fernando S, Marasinghe RB. Using the DREEM questionnaire to gather baseline informationon an evolving medical school in Sri Lanka. Medical Teacher.2005; 7: 348-52.

12. Mayya S. Roff S. Students' Perceptions of Educational Environment : A Comparison of Academic Achievers and Under-Achievers at Kasturba Medical College, India. Education for Health. 2004;17: 280-291.

13. McAleer S, Roff S. A practical guide to using the Dundee Ready Education Environment Measure(DREEM) 2003. http://web.onetel.net.uk/mikeharris/waco/dreems2.doc

14. Demiroren M, Palaoglu O, Kemahli S, Ozyurda F, Ayhan HI. Perceptions of Students in Different

Phases of Medical Education of Educational Environment: Ankara University Faculty of Medicine. 2008. http.//www.med-edonline.org

15. Abraham RR, Ramnarayan K, Pallath V, Torke S, Madhavan M, Roff S. Perceptions of academic achievers and under achievers regarding learning environment of Melaka Manipal Medical College (Manipal campus), Manipal India, using DREEM the Inventory. South East Asian Journal of Medical Education, Inaugural issue. 2008; 18-24.

16. Seabrook MA, Clinical students' initial reports of the educational climate in a single medical school. Medical Education.2004; 38: 659-69. 
Table 1: Mean total DREEM and domain scores of the three groups of students.

\begin{tabular}{|c|c|c|c|c|c|}
\hline \multirow{2}{*}{ Domain of DREEM } & \multirow[t]{2}{*}{ Maxi-mum score } & \multicolumn{3}{|c|}{ Mean } & \multirow[b]{2}{*}{$\begin{array}{l}\mathrm{p}<0 \\
.05\end{array}$} \\
\hline & & $\begin{array}{l}3^{\text {rd }} \text { Year } \\
(\mathrm{n}=475)\end{array}$ & $\begin{array}{l}4^{\text {th }} \text { Year } \\
(\mathrm{n}=989)\end{array}$ & $\begin{array}{l}5^{\text {th }} \text { Year } \\
(\mathrm{n}=439)\end{array}$ & \\
\hline $\begin{array}{l}\text { 1.Student's Perceptions of } \\
\text { Learning (SPL) }\end{array}$ & 48 & 31.08 & 27.41 & 25.42 & $\begin{array}{c}1,2, \\
3\end{array}$ \\
\hline $\begin{array}{l}\text { 2.Student's Perceptions of } \\
\text { Teachers (SPT) }\end{array}$ & 44 & 27.00 & 23.86 & 22.61 & $\begin{array}{c}1,2 \\
3\end{array}$ \\
\hline $\begin{array}{l}\text { 3.Student's Academic Self- } \\
\text { Perceptions (SASP) }\end{array}$ & 32 & 20.72 & 19.17 & 19.00 & 1,3 \\
\hline $\begin{array}{l}\text { 4.Student's Perceptions of } \\
\text { Atmosphere (SPA) }\end{array}$ & 48 & 25.93 & 23.85 & 23.73 & 1,3 \\
\hline $\begin{array}{l}\text { 5.Student's Social } \\
\text { Perceptions (SSSP) }\end{array}$ & 28 & 14.74 & 14.12 & 14.57 & 1 \\
\hline Total DREEM score & 200 & 119.51 & 108.38 & 105.30 & $\begin{array}{c}1,2, \\
3\end{array}$ \\
\hline
\end{tabular}

1 , represents $p<0.05$ difference between year 3 and 4

2 , represents $\mathrm{p}<0.05$ difference between year 4 and 5

3 , represents $\mathrm{p}<0.05$ difference between year 3 and 5

Table 2: Mean score for each DREEM item of the three groups of students

$\underline{\text { Domain }}$

$\underline{\text { Item }}$

Mean score (max. score 4)

$\underline{3}^{\text {rd }}$ year $\underline{4}^{\text {th }}$ year $\quad \underline{5}^{\text {th }}$ year $\quad p<0$.

SPL 1.I am encourage to participate in classes $\quad 3.09$

7.The teaching is often stimulating

3.33

2.91

2.62

05

13.The teaching is student centred

1.64

3.22

3.08

$1,2,3$

16.The teaching helps to develop my 3.12

1.28

1.11

$1,2,3$

competence

20.The teaching is well focused

2.55

2.92

2.71

$1,2,3$

22.The teaching helps to develop my

confidence

24. The teaching time is put to good use

2.71

2.78

2.46

1,3

25.The teaching overemphasizes factual learning

38.I am clear about the learning objectives

of the course

$\begin{array}{lll}2.38 & 2.37 \quad 1,3\end{array}$

44. The teaching encourages me to be an

2.99

2.72

2.54 
47.Long term learning is emphasized over 2.88 short term learning

48.The teaching is too teacher centred $\quad 1.76$

SPT

2.The teachers are knowledgeable

6.The teachers are patient with patients

3.34

2.87

8.The teachers ridicule the students

9.The teachers are authoritarian

1.01

2.03

18.The

teachers

have good 2.55 communication skills with patients

29. The teachers are good at providing

2.56

feedback to students

32.The teachers provide constructive criticism here

37. The teachers give clear examples

2.81

39. The teachers get angry in class

40.The teachers are well prepared for their class

50.The students irritate the teachers

2.68

SASP

5.Learning strategies which worked for

2.29

me before continue to work for me now

10.I am confident about my passing this year

21.I feel I am being well prepared for my profession

26.Last year's work has been a good 2.99 preparation for this year's work

27.I am able to memorize all I need

1.88

31.I have learned a lot about empathy in

2.99

my profession

41.My problem-solving skills are being

2.48

well developed here

45.Much of what I have to learn seems

2.96 relevant to a career in medicine

SPA
11.The atmosphere is relaxed during the 1.80 ward teaching

12.This college is well time-tabled

17. Cheating is a problem in this college

23.The atmosphere is relaxed during 1.79 lectures

30.There are opportunities for me to 2.74 develop inter-personal skills

33.I feel comfortable in class socially $\quad 3.08$

34.The atmosphere is relaxed during 2.07 tutorials /seminars
2.51

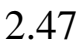

\section{1,3}

1.30

1.08

$1,2,3$

$3.10 \quad 2.95$

$1,2,3$

2.38

2.39

1,3

1.17

1.14

1,3

1.69

1.65

1,3

2.12

2.03

1,3

2.18

1.83

$1,2,3$

2.09

1.92

$1,2,3$

2.45

2.34

$1,2,3$

1.69

1.51

$1,2,3$

2.56

2.43

$1,2,3$

2.57

2.50

3

$2.17 \quad 2.15 \quad$ NS

$\begin{array}{lll}2.56 & 2.48 \quad 1,3\end{array}$

2.31

2.24



2.76

2.65

1,3

1.71

1.80

1

2.76

2.73

$2.22 \quad 2.28$

1,3

$2.75 \quad 2.72 \quad 1,3$

$1.61 \quad 1.63 \quad 1,3$

2.63

2.23

$1,2,3$

1.59

1.44

2

1.77

1.96

2,3

$2.48 \quad 2.61$

$1,2,3$

2.96

3.01

1

1.97

2.03

NS 


\begin{tabular}{|c|c|c|c|c|}
\hline 35.I find the experience disappointing & 1.78 & 1.47 & 1.39 & 1,3 \\
\hline 36.I am able to concentrate well & 2.51 & 2.26 & 2.24 & 1,3 \\
\hline $\begin{array}{l}\text { 42. The enjoyment outweighs the stress of } \\
\text { studying medicine }\end{array}$ & 1.61 & 1.58 & 1.61 & NS \\
\hline $\begin{array}{l}\text { 43. The atmosphere motivates me as a } \\
\text { learner }\end{array}$ & 2.24 & 2.11 & 2.00 & 1,3 \\
\hline 49.I feel able to ask the questions I want & 1.85 & 1.52 & 1.66 & $1,2,3$ \\
\hline $\begin{array}{l}\text { 3.There is a good support system for } \\
\text { students who get stressed }\end{array}$ & 1.39 & 1.18 & 0.97 & $1,2,3$ \\
\hline 4.I am too tired to enjoy the course & 1.47 & 1.28 & 1.45 & 1,2 \\
\hline 14.I am rarely bored on this course & 1.82 & 1.81 & 1.83 & NS \\
\hline 15.I have good friends in this college & 3.25 & 3.09 & 3.16 & 1 \\
\hline 19.My social life is good & 3.00 & 2.81 & 3.00 & 1,2 \\
\hline 28.I seldom feel lonely & 2.33 & 2.22 & 2.37 & 2 \\
\hline 46.My accommodation is pleasant & 1.54 & 1.78 & 1.83 & 1,3 \\
\hline
\end{tabular}

1 , represents $\mathrm{p}<0.05$ difference between year 3 and 4

2 , represents $p<0.05$ difference between year 4 and 5

3 , represents $p<0.05$ difference between year 3 and 5 